\title{
METHODS OF SERVICE QUALITY ASSESSMENT - PRELIMINARY RESULTS OF SURVEY FOR ENTERPRISES
}

\author{
Manuela Ingaldi \\ Department of Production Engineering and Safety, Faculty of Management, \\ Czestochowa University of Technology, al. Armii Krajowej 19b, 42-200 Czestochowa, Poland \\ E-mail: manuela@gazeta.pl
}

\begin{abstract}
There are many service enterprises on the market, which offers different type of services practically every day. Quality assessment of such services is very difficult. There are many methods that can be used in such a situation, but it should be emphasized that in such researches customers' opinions are usually used. The purpose of the paper is to present a survey on the use of methods of service quality assessment. In the paper preliminary results of the survey from point of view of the service enterprises are presented. The enterprises were asked to indicate what methods they used, what information they received thanks to such research, what happened to the obtained results and what problems they encountered. Preliminary research was carried out between September and December 2017. The research will be continued throughout 2018. At the same time, the research is conducted from the point of view of the customers of such enterprises. The final results of the research will help the service enterprises to choose right research method and can be used by various service companies.
\end{abstract}

Keywords: quality, quality analysis, service, survey.

JEL Classification: D20, L15, L60, M11.

\section{Introduction}

Services are present at every step of our lives. We use some of them every day, others only from time to time, without being aware of it. It should be remembered that there is a lot of competition on the service market. Enterprises must fight to survive and to convince customers to their services (Borkowski, Ulewicz, Selejdak, Konstanciak, \& Klimecka-Tatar, 2012; Kotus, Holota, Paulicek, Petrik, \& Sklenar, 2013; Chen \& Barrows, 2015; Nilsson-Witell \& Fundin, 2005).

In addition to the price, which is often a decisive element for customers, the services must be properly prepared, manufactured, delivered. That is why it is so important to maintain the quality of services by enterprises. Service enterprises have begun to look for appropriate solutions, methods that could help in assessing the quality of these services (Frost \& Kumar, 2000; Ulewicz, 2014; Guglielmetti, 2001; Galgano, 1993; Rivière, Monrozier, Rogeaux, Pagès, \& Saporta, 2006).

Unfortunately, in contrast to products quality, service quality is difficult to be assessed (Kardas, 2016; Ingaldi \& Jursova, 2013; Dulska, Studnicki, \& Szajnar, 2017). In the available literature (Frąś, 2014; Kujawiński, 1998; Wong, Hideki, \& George, 2011; Matzler, Bailom, Hinterhuber, Renzl, \& Pichler, 2004; Stoma, 2012), the various methods of the service quality assessment are described in detail, it is possible to find a lot of practical studies on this topic. But in addition to scientific applications, they also have real, practical application. Many enterprises use these methods to assess their services. Some of these methods are more popular, others less.

The most popular methods of service quality assessment, according to literature are Servqual, CIT, Mystery Shopper and different types of indexes. While those methods, which are often skipped, are for example Servperf, IPA, Kano, penalty/rewards, problem detecting (Frąś, 2014; Stoma, 2012).

The most difficult element of the service quality assessment is actually the proper choice of method and the creation of an appropriate tool in the form of e.g. a questionnaire. Such method should provide as much information as possible about the quality of services offered by the enterprise, so that the research problem can be truly reflected. On the other hand, such method often involves a large number of employees, customers, creates a large amount of data for analysis (Stoma, 2012; Parasurman, Zeithaml, \& Berry, 1985; Reichheld, 2003; Wong et al, 2011).

It should be remembered that customers always have to take part in such assessments, they 
are the source of information and data that are analysed. Unfortunately, they are not always eager to help, to answer questions, and often if they do, they do not care about it. Often such analyses is too long according to customers, it contains difficult terms, so they do not want to waste their time. Very often they fill in surveys carelessly, answer questions randomly or interrupt the study when they get bored (Ciavolino \& Calcagni, 2015; Gołąb-Andrzejak \& Badzińska, 2015; Lupo, 2015; Mbise \& Tuninga, 2016).

Appropriate methods of the service quality assessment may affect the information that the enterprise can obtain in this way, and thus this enterprise can effectively manage the quality of its services. Therefore, properly selected method and questions addressed to the customers are the basis for the success of such research (Abalo, Varela, \& Manzano, 2007; Cho, Kim, \& Kwak, 2016; Ingaldi, 2016; Mahmoud \& Khalifa, 2015).

The purpose of the paper is to present a survey on the use of methods of the service quality assessment. In the paper preliminary results of the survey from point of view of the service enterprises are presented. The enterprises were asked to indicate what methods they used, what information they received thanks to such research, what happened to the obtained results and what problems they encountered. Preliminary research was carried out between September and December 2017. The research will be continued throughout 2018. At the same time, the research is conducted from the point of view of the customers of such enterprises.

\section{Methodology}

The research on the use of methods of the service quality assessment was carried out in the form of a questionnaire. The survey covered service enterprises from the region of Czestochowa (Poland). The questionnaire was developed by the author of this paper and it is a part of a larger research project.

The questionnaire consisted of three sections: introductions to the questionnaire, proper questions and respondents characteristics. The introduction provides a brief description of the research and a formula with a request to fill in the questionnaire. In the main part, 22 questions were mentioned. In the first four questions the approach to the quality of services and customers was assessed. Next questions concerned the methods of the service quality assessment and their use by the research enterprises. Respondents were also asked how they develop the results of such research, the use of these results, but also about the problems they encounter.

The responses include the option "I have no opinion" or "I do not know", because the respondents could be ordinary employees or employees not from quality departments who do not know the details of the enterprise's operation in this area.

The respondent data section includes 4 different characteristics of the participants.

In the survey different type of questions were used to additionally assess how people respond to them and if they have will to do it. All questions were obligatory due to the fact that in the title and description of the survey its purpose was clearly indicated.

A Google form was used to construct the survey. This enabled a quick correction in case of stylistic, grammatical errors, etc. It also helped in reaching a wider group of respondents and facilitated data collection.

The link to the surveys was sent by e-mail to service enterprises from the research area. The questionnaire was also made available through various websites, social networks.

In the article, only the most important results are presented due to the editorial limitation. This is a preliminary research, treated as pilot research.

The pilot research covered 42 enterprises. Its purpose was to check the willingness of cooperation on the part of the service enterprises from the region of Czestochowa, to evaluate the proposed survey and to check potential errors. It will also help in identifying the initial results and applications.

\section{Results}

In the first question respondents were asked about the approach to the customer in their enterprise (Table 1). They could choose more than one answer. $83.6 \%$ of respondents replied that they should take care of the customer's good, $66.7 \%$ indicated that each customer may have different requirements, while $56.7 \%$ that each customer is different. Therefore it can be concluded that the research enterprises put the customer as an important element to care for. However, they do not indicate that the customer is the most important.

In the next question respondents were asked to indicate definition of service quality according to their customers (Table 2). The answer „meeting customer requirements" was the one indicated that the most often ( $86.7 \%$ of respondents). This is an important judgment of the entrepreneurs, because 
the customer decides to use the service, he chooses the service and the service provider. That is why meeting his requirements is so important.

Table 1. What is the approach to the customer in your enterprise? (option to choose more than one answer) (source: own study)

\begin{tabular}{|l|c|}
\hline \multicolumn{1}{|c|}{$\begin{array}{c}\text { What is the approach } \\
\text { to the customer in your enterprise? }\end{array}$} & $\begin{array}{c}\text { Percentage } \\
\text { fraction }\end{array}$ \\
\hline Customer is the most important & 30.0 \\
\hline Each customer is different & 56.7 \\
\hline $\begin{array}{l}\text { Each customer may have different } \\
\text { requirements }\end{array}$ & 66.7 \\
\hline $\begin{array}{l}\text { We should take care of the customer's } \\
\text { good }\end{array}$ & 83.6 \\
\hline $\begin{array}{l}\text { The number of served customers is } \\
\text { important regardless of their } \\
\text { satisfaction }\end{array}$ & 10.2 \\
\hline Profit is important, not the customer & 3.3 \\
\hline I do not know & 0.0 \\
\hline Other & 0.0 \\
\hline
\end{tabular}

According to respondents the service quality can be defined by precision of execution $(66.7 \%$ of respondents) and price adequate to the service $(63.3 \%)$. The precision of execution can affect meeting of customers' requirements and perception of the finished service. The degree of compliance of individual service characteristics depend on the precision of execution. However, the price is often one of the factors that determine the purchase of a given service. Many people in Poland, when using a variety of services, are unfortunately forced to choose this factor.

In the next question, it was checked which methods of the service quality assessment were most often used by Polish enterprises (Figure 1). Respondents replied that they most often used chosen satisfaction indexes (60\% of respondents), chosen customer loyalty indexes (43.3\%) and own surveys of service quality assessment $(42.8 \%)$. The methods, which are the most often described in the literature, i.e. Servqual, IPA, CIT, Mystery Shopper are often skipped. It is not known whether this is due to the ignorance of these research methods, or perhaps the belief in the difficulty of their use.

It was also checked who usually collected data on the service quality for the research enterprises (Figure 2). Most often it is a designated employee of the enterprise (33.3\%) or e-form (i.e. customer) $(26.1 \%)$, less often a executive's representatives
(20.1\%). Only in $10.5 \%$ of cases it is an external person. Polish enterprises do not want to outsource such research to other enterprises or external people, they prefer to do them themselves. Some data is collected in paper or electronic form, so no one is needed. Perhaps this is due to the fact that the majority of service enterprises are small once that decide for financial reasons for their own research.

Table 2. How do you think, what defines the service quality according to customers? (option to choose more than one answer) (source: own study)

\begin{tabular}{|l|c|}
\hline \multicolumn{1}{|c|}{$\begin{array}{c}\text { How do you think, what defines } \\
\text { the service quality according } \\
\text { to customers? }\end{array}$} & $\begin{array}{c}\text { Percentage } \\
\text { fraction }\end{array}$ \\
\hline Meeting customer requirements & 86.7 \\
\hline A large range of services & 33.3 \\
\hline A large selection of service features & 26.8 \\
\hline $\begin{array}{l}\text { The amount of information available } \\
\text { about the service }\end{array}$ & 50.0 \\
\hline $\begin{array}{l}\text { Possibility to change the service at } \\
\text { various stages of its provision }\end{array}$ & 36.5 \\
\hline Speed of execution & 47.9 \\
\hline Precision of execution & 66.7 \\
\hline Friendly service providers & 46.7 \\
\hline Experienced service providers & 53.3 \\
\hline Helpful service provider & 56.8 \\
\hline $\begin{array}{l}\text { Place of providing the service } \\
\text { at the appropriate level, }\end{array}$ & 20.2 \\
\hline Satisfaction with the provided services & 52.3 \\
\hline Price adequate to the service & 63.3 \\
\hline I do not know & 0.0 \\
\hline Other & 0.0 \\
\hline
\end{tabular}

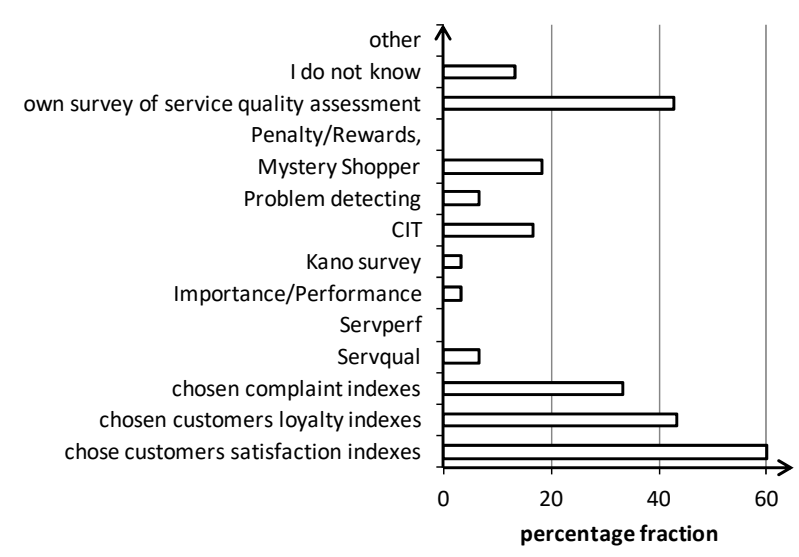

Figure 1. What method of the quality service assessment is used in your enterprise? (option to choose more than one answer) (source: own study) 


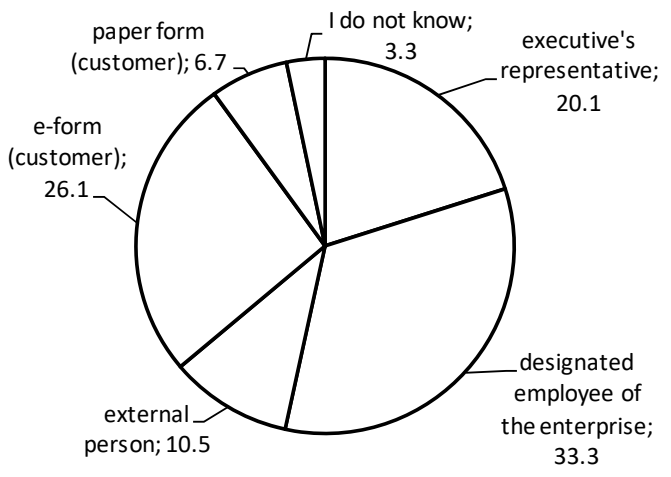

Figure 2. Who usually collects data on the quality of services? (source: own study)

It was also checked, what form of data collection was used in the research enterprise (Table 3). In Polish service enterprises, it is most often a direct conversation straight after the service provision (direct interview) (46.7\%) and online survey (40.8\%). These are two extremely different forms of data collection. The first form contains an element of the first impression on the part of the customer, often in such situations the customer is unable to indicate the good or bad sides of a given service, based on the first felling towards the service. The second one contains some thoughts, a sentence after getting familiar with the given service.

$10.2 \%$ respondents chose answer "other". Among the additions of the answers in this option, regular telephone interviews, evaluation sheet, complaint sheet, other documents were mentioned.

Table 3. What form of data collection is used in your enterprise? (option to choose more than one answer) (source: own study)

\begin{tabular}{|l|c|}
\hline \multicolumn{1}{|c|}{$\begin{array}{c}\text { What form of data collection } \\
\text { is used in your enterprise? }\end{array}$} & $\begin{array}{c}\text { Percentage } \\
\text { fraction }\end{array}$ \\
\hline $\begin{array}{l}\text { Direct conversation straight after the } \\
\text { service provision (direct interview) }\end{array}$ & 46.7 \\
\hline $\begin{array}{l}\text { Telephone call after service provision } \\
\text { (direct interview after the customer's } \\
\text { visit) }\end{array}$ & 26.7 \\
\hline Paper survey handed to the customer & 32.1 \\
\hline Paper survey placed in the lobby & 13.3 \\
\hline Online survey & 40.8 \\
\hline $\begin{array}{l}\text { Business card with a link to an online } \\
\text { survey }\end{array}$ & 12.5 \\
\hline E-mail with questions or survey & 20.1 \\
\hline Survey for Mystery Shopper & 13.3 \\
\hline I do not know & 6.7 \\
\hline Other & 10.2 \\
\hline
\end{tabular}

Respondents had different opinions about the basis of choosing the research method (Table 4). Mostly they were guided by the previous experience of conducting research (67.9\%). Perhaps this is the reason why they do not use the research methods which are the most often described in the literature. Especially that the available literature is very often omitted by them (only $3.6 \%$ ). The enterprises used also information from employees (35.2\%) and external consulting (30.2\%).

Table 4. On what basis does your enterprise choose the method of the service quality assessment? (option to choose more than one answer) (source: own study)

\begin{tabular}{|l|c|}
\hline $\begin{array}{c}\text { On what basis does your enterprise } \\
\text { choose the method of the service quality } \\
\text { assessment? }\end{array}$ & $\begin{array}{c}\text { Percent- } \\
\text { age } \\
\text { fraction }\end{array}$ \\
\hline $\begin{array}{l}\text { Previous experience of conducting } \\
\text { research }\end{array}$ & 67.9 \\
\hline Based on available literature & 3.6 \\
\hline External consulting & 30.2 \\
\hline Benchmarking & 16.7 \\
\hline Based on information from employees & 35.2 \\
\hline I do not know & 0.0 \\
\hline Other & 0.0 \\
\hline
\end{tabular}

There are many reasons for the choice of research methods that are important for the research enterprises (Table 5). First of all, the respondents took into consideration ease of use (52.3\%) and the amount of gained data (46.5\%). Again, this explains the omission of the methods of the service quality assessment which are frequently described in the literature. These methods are more complicated, require more work and take time to learn how to use them.

Other important features that affect selection are the form of gathering data $(36.8 \%)$ and the possibility of drawing conclusions (33.3\%). Although this may be surprising, because for example the online survey frequently used by the research enterprises (Table 3) may be used in case of the Servqual or other method, it needs only proper construction.

An interesting conclusion can be drawn in case of the question about the types of questions that bring the most information to the research enterprises (Figure 3). A question about the opinion was indicated by $42.7 \%$ of respondents. Despite this, the respondents differently treated similar type of questions in the survey presented in this paper. Sometimes they marked the answer "other" but 
they did not provide additional answer. And it's like denying themselves.

Table 5. Which feature of the method decided about its choice? (option to choose more than one answer) (source: own study)

\begin{tabular}{|l|c|}
\hline $\begin{array}{c}\text { Which feature of the method decided } \\
\text { about its choice? }\end{array}$ & $\begin{array}{c}\text { Percentage } \\
\text { fraction }\end{array}$ \\
\hline Complexity of the method & 16.7 \\
\hline Ease of use & 52.3 \\
\hline Amount of gained data & 46.5 \\
\hline Number of respondents & 13.3 \\
\hline Number of involved employees & 23.9 \\
\hline Form of gathering data & 36.8 \\
\hline $\begin{array}{l}\text { Methodology for the results develop- } \\
\text { ment }\end{array}$ & 23.9 \\
\hline Possibility of drawing conclusions & 33.3 \\
\hline I do not know & 16.7 \\
\hline Other & 0.0 \\
\hline
\end{tabular}

For the respondents a closed question with one answer (36.08\%) and with multiple choice $(42.3 \%)$ are also important. In such questions, it is easier to limit potential answers of respondents and avoid mistakes but also to have an impact on respondents' answers, giving only the once "correct" and avoiding potential "problematic".

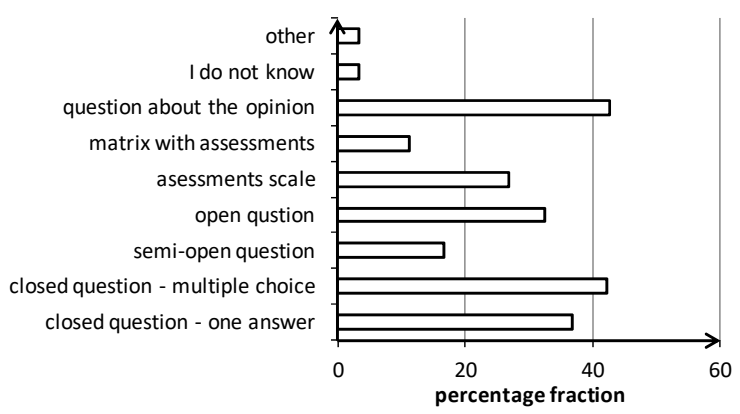

Figure 3. What type of questions, according to you, brings more data to your enterprise? (option to choose more than one answer) (source: own study)

While conducting research on the service quality, the frequency of data collection is also important (Figure 4). After all, the ability and speed of responding to quality problems and taking into account customer feedback depend on it. $36.7 \%$ respondents do it ongoing, constantly (request to each customer) and $21.2 \%$ ongoing, constantly (specific number of customers). This form gives the opportunity to quickly respond to the negative elements of the customer's assessment.

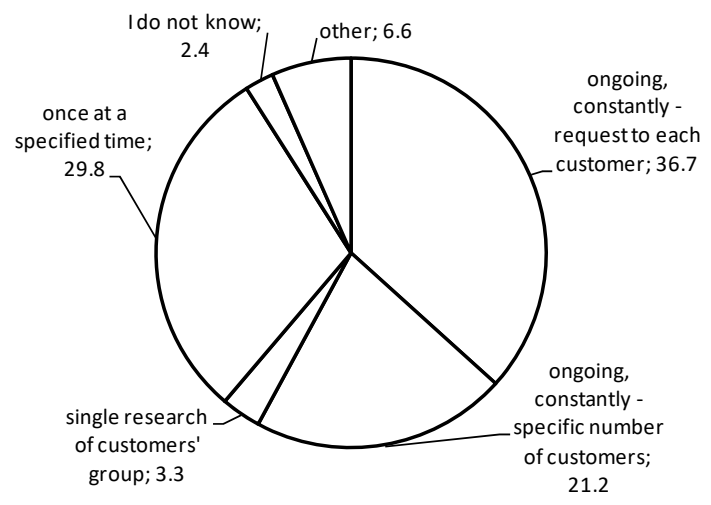

Figure 4. How often is data collected from customers? (source: own study)

Unfortunately, during the research it is possible to encounter various problems that affect the course of these research (Table 6). In the case of data collection from customers by Polish service enterprises, the biggest problem is a refusing to participate in the research $(53.3 \%)$. Customers are not willing to participate in such activities. If they do, they are often reluctant, without commitment. It should be emphasized that in the case of service quality assessment, in most methods there are customers who are the data source.

Other, often mentioned problems are avoiding questions and interrupting the research (each $42.5 \%$ ). The result is that the survey or research does not have full value and it is not known whether this data should be included as research material or not. Although it may be a signal that the research method needs improvement.

A small percentage of respondents indicated the answer "other". Among the additional answers provided directly by the respondents are: diplomatic responses, insufficient approach.

An important element of any research is to develop the results and to draw conclusions. The analysis should take place in a time similar to the data collection, because only in this way the enterprise can improve the service. What's more, it should be remembered that the situation of the enterprise, offered services, or customer preferences are constantly changing. So too late analysis and drawing conclusions will be unnecessary in changed operating conditions.

Therefore, there was a question about how often the research enterprises develop the results (Figure 5). 15.9\% of respondents answered that once a month, $33.8 \%$ once a quarter, and $26.9 \%$ once a half year. This means that the research enterprises try to analyze feedback on the services they have received from customers on an ongoing basis in order to improve their services. 
Table 6. What problems do you face while collecting data from customers? (option to choose more than one answer) (source: own study)

\begin{tabular}{|l|c|}
\hline \multicolumn{1}{|c|}{$\begin{array}{c}\text { What problems do you face while } \\
\text { collecting data from customers? }\end{array}$} & $\begin{array}{c}\text { Percentage } \\
\text { fraction }\end{array}$ \\
\hline Refusing to participate in the research & 53.3 \\
\hline $\begin{array}{l}\text { Refusing to answer one or several } \\
\text { questions }\end{array}$ & 31.2 \\
\hline Avoiding questions & 42.5 \\
\hline Wrongly filled out answers & 31.2 \\
\hline Random answers & 3.3 \\
\hline $\begin{array}{l}\text { More responses were indicated than re- } \\
\text { quired }\end{array}$ & 16.7 \\
\hline Avoiding answer "other" & 18.2 \\
\hline $\begin{array}{l}\text { Marking the answer "other", but with- } \\
\text { out providing another option }\end{array}$ & 23.4 \\
\hline Avoiding open questions & 25.7 \\
\hline Interrupting the research & 42.5 \\
\hline Adding unnecessary comments & 6.6 \\
\hline Illegible handwriting & 15.2 \\
\hline Answers not connected to questions & 12.1 \\
\hline I do not know & 6.7 \\
\hline Other & 3.3 \\
\hline
\end{tabular}

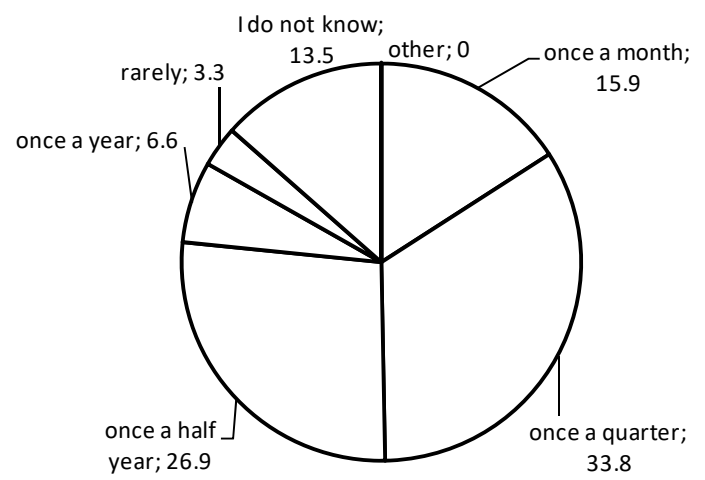

Figure 5. How often are research results developed in the enterprise? (source: own study)

Not only the frequency of the results development is important, but also the form of their presentation (Figure 6). Respondents indicated that their results were usually presented in the form of reports $(63.3 \%)$. Basic statistics (42.5\%) are also commonly used, what allow to compare results in different research periods, and conclusions with proposals for improvement $(36.7 \%)$. The conclusions are very important, because it is the purpose of conducting research: checking the level of service quality, but also determining possible corrective actions.

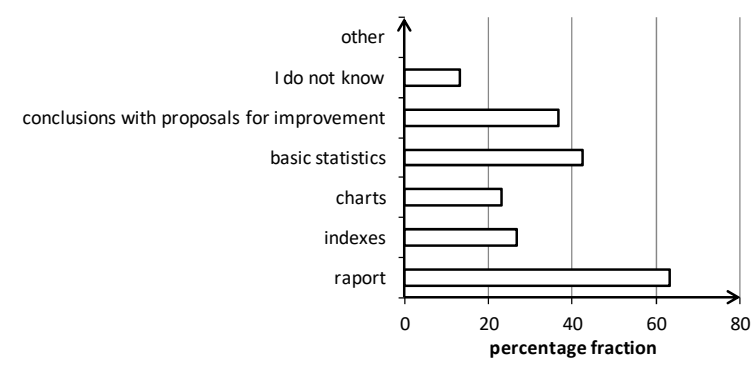

Figure 6. How are the research results published? (option to choose more than one answer)

(source: own study)

In addition to problems in the data collection during the research, very often a variety of problems also occur during the development of results (Table 7). Only $15.9 \%$ of respondents do not encounter any problems.

The biggest problem in the development of results are incomplete data $(57.2 \%)$, which coincides with problems in the data collection. Because it is not known whether incomplete data should be considered or omitted.

Another problem is too few respondents, which makes that the sample is not representative (36.7\%). Again, this coincides with the question of problems with data collection, as customers refuse to participate in the research.

Table 7. What problems do you face while developing results? (option to choose more than one answer) (source: own study)

\begin{tabular}{|l|c|}
\hline \multicolumn{1}{|c|}{$\begin{array}{c}\text { What problems do you face while } \\
\text { developing results? }\end{array}$} & $\begin{array}{c}\text { Percent- } \\
\text { age } \\
\text { fraction }\end{array}$ \\
\hline $\begin{array}{l}\text { Too few respondents - the sample is } \\
\text { not representative }\end{array}$ & 36.7 \\
\hline Too many questions & 12.1 \\
\hline Too many answers & 13.3 \\
\hline Too few answers & 16.7 \\
\hline Rarely developed results & 23.3 \\
\hline Too fancy charts & 13.3 \\
\hline $\begin{array}{l}\text { Mismatch of the forms of developing } \\
\text { results with the method }\end{array}$ & 3.3 \\
\hline Incomplete data & 57.2 \\
\hline I do not know & 12.1 \\
\hline We do not have any problem & 15.9 \\
\hline Other & 0.0 \\
\hline
\end{tabular}

Respondents were asked what happened with the results of their research (Figure 7). They replied that the most important conclusions were 
drawn and they indicated areas that needed improvement (61.2\% each). This is a positive aspect of the research enterprise and their service quality assessment. Because it indicates that such researches are purposeful and necessary.

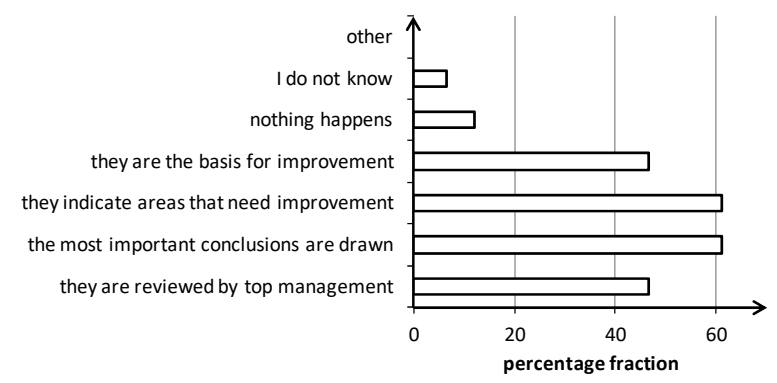

Figure 7. What happens to the results? (option to choose more than one answer) (source: own study)

In the next question respondents were asked if the results of the research were used to determine the enterprise's strategy (Figure 8). This is important because for service enterprises providing services, to meet the requirements of customers is a priority.

Respondents replied that the results are always $(20 \%)$ or sometimes $(60 \%)$ part of the strategy. This is a positive result because whether or not research results should be the basis for developing a strategy depends on whether it is really needed. Good that enterprises think about it.

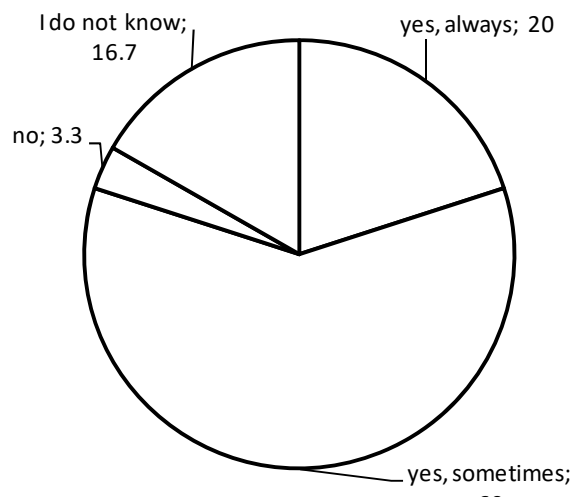

60

Figure 8. Are the results a material to determine the enterprise's strategy? (source: own study)

Respondents were asked if the results were published somewhere (Figure 9). Only 6.6\% of respondents confirmed. $36.6 \%$ of them did not know the answer to this question. If the results are published, then according to the respondents, they are published on the enterprise's website or as a newsletter.

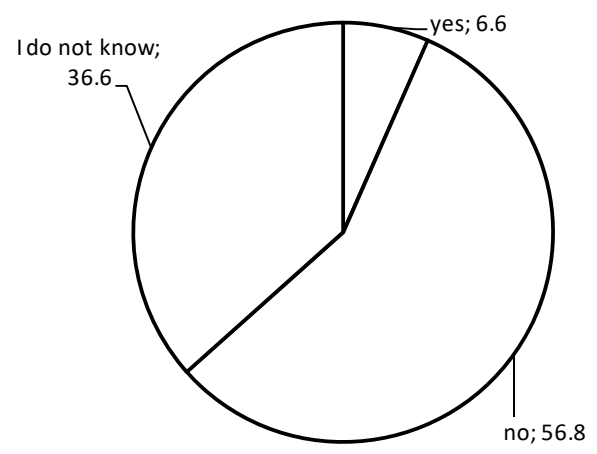

Figure 9. Are the results published somewhere? (source: own study)

An important element of research and development of the results of any research in the company is to present them to employees (Figure 10). This is particularly important in the case of service enterprises. They are often small enterprises where most or all employees participate in the provision of services. And these employees should know how the services are perceived by customers and what should be improved.

In the case of the research service enterprises, in $42.5 \%$ of them, all employees are familiarized with the results. Only $12.1 \%$ of respondents denied such a situation.

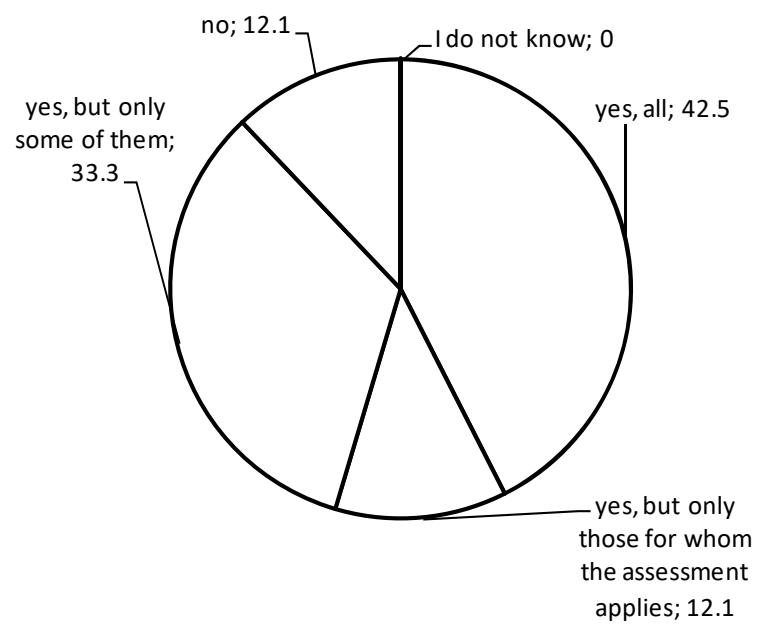

Figure 10. Are employees familiar with them? (source: own study)

\section{Conclusions}

In the paper a pilot research on the use of methods of the service quality assessment from the point of view of service enterprises was presented. The preliminary research covered 42 enterprises from Czestochowa region. The research took the form of a survey. Some surveys were omitted because they were incomplete or had errors. 
The most important results of pilot research are:

- For research enterprises "meeting customer requirements" is the base of their approach to the customers. The service quality can be defined by precision of execution and price adequate to the service.

- Enterprises that took part in the survey use mainly various types of indexes and their own surveys. The most often described methods of the service quality assessment are often omitted. It is not known what the reason is, perhaps ignorance of methods. And these methods also suggest how to present the results and their interpretation.

- The data for the service quality assessment are the most often collected by designated employee of the enterprise or eform (i.e. customer). They are collected in a direct conversation straight after the service provision (direct interview) and in a form of the online survey. Most respondents do it ongoing, constantly (request to each customer) or ongoing, constantly (specific number of customers).

- A question about the opinion is the one which brings more data to the enterprises. But for the respondents a closed question with one answer and with multiple choice are also important.

- Very often the answer "other" was marked, but no additional answer was given. The respondents did not want to express themselves in the semi-open questions, although asking for an opinion was one of the questions that bring the most information to these enterprises. So respondents act in a way that is opposite to their opinion.

- There are lots of problems during such research. First of all people refuse to participate. If they agree to do it they often avoid questions or interrupt the research. When developing results there is a problem with incomplete data or non-representative sample.

- The results of such analysis are developed once a quarter or once a half year. Later the results are presented in a form of reports or basic statistics. Later results are often used a material to determine the enterprise's strategy.
Thanks to pilot studies, it was possible to observe the reaction of service enterprises to the survey. It was possible to find out how the respondents answered the questions and to introduce a small correction to the questionnaire before main study is conducted.

As already mentioned, there are already some conclusions regarding the use of individual methods and the type of questions which are prefered by the enterprises.

The selection of an appropriate research method is not easy. It is influenced by many factors. They should all be taken into account and all the pros and cons should be examined. This is particularly important when choosing the method of the service quality assessment.

It should also be remembered that the use of customers when analyzing the service quality, their opinions is not easy, because we have no influence on how they answer questions, whether they do it conscientiously. There is even one thing more important, what the management of the enterprise will do with the information obtained in this way.

In the paper only preliminary results are presented while the research is continued in 2018. At the same time, research is conducted from the point of view of the customers of these enterprises. In the future there results form both points of view will be compared.

Thanks to the research, it will be possible to indicate methods of the service quality assessment most often used by Polish enterprises, to determine the manner of conducting such an assessment according to the opinions of customers and service providers, to determine the most frequent problems faced by customers and service providers.

\section{References}

Abalo, J., Varela, J., \& Manzano, V. (2007). Importance values for Importance-Performance Analysis: A formula for spreading out values derived from preference rankings. Journal of Business Research, 60(2), 115-121. https://doi.org/10.1016/j.jbusres.2006.10.009

Borkowski, S., Ulewicz, R., Selejdak, J., Konstanciak, M., \& Klimecka-Tatar, D. (2012). The use of $3 \times 3$ matrix to evaluation of ribbed wire manufacturing technology. In $21^{S T}$ International Conference on Metallurgy and $\mathrm{Ma}$ terials (METAL 2012) (pp. 1722-1728). Brno, Czech Republic. Tanger, Ostrava.

Chen, R. J. C., \& Barrows, C. W. (2015). Developing a mystery shopping measure to operate a sustainable restaurant business: The power of integrating with corporate executive members' feedback. Sustainability, 7(9), 12279-1229. https://doi.org/10.3390/su70912279 
Cho, I. J., Kim, Y. J., \& Kwak, C. (2016). Application of SERVQUAL and fuzzy quality function deployment to service improvement in service centres of electronics companies, Total Quality Management \& Business Excellence, 27(3-4), 368-381. https://doi.org/10.1080/14783363.2014.997111

Ciavolino, E., \& Calcagni, A. (2015). Generalized cross entropy method for analysing the SERVQUAL model. Journal of Applied Statistics, 42(3), 520-534. https://doi.org/10.1080/02664763.2014.963526

Dulska, A., Studnicki, S., \& Szajnar, J. (2017). Reinforcing cast iron with composite insert, Archives of Metallurgy and Materials, 62(1), 355-357. https://doi.org/10.1515/amm-2017-0054

Frąś, J. (2014). Wybrane instrumenty pomiaru jakości usług logistycznych (Zeszyty Naukowe Uniwersytetu Szczecińskiego 803). Finanse, Rynki Finansowe, Ubezpieczenia, 66, 297-317.

Frost, F. A., \& Kumar, M. (2000). INTSERVQUAL: an internal adaptation of the GAP model in a large service organization. Journal of Services Marketing, 14(5), 358-377. https://doi.org/10.1108/08876040010340991

Galgano, A. (1993). La qualità Totale: il Company-Wide Quality Control come nuovo sistema manageriale $\left(1^{\text {st }}\right.$ ed.). Milano: Il Sole 24 ore.

Gołąb-Andrzejak, E., \& Badzińska, E. (2015). Satysfakcja klientów jako źródło sukcesu organizacji - studium przypadku (Zeszyty Naukowe Uniwersytetu Szczecińskiego 875). Problemy Zarządzania, Finansów i Marketingu, 41(1), 81-91.

Guglielmetti, R. (2001). L'attenzione al cliente: approccio teorico. In L. Cappelli, \& M. F. Renzi (Eds.), Management della qualità. Padova: CEDAM.

Ingaldi, M. (2016). Use of the SERVPERF method to evaluate service quality in the transport company. Independent Journal of Management and Production, 7(1), 168177. https://doi.org/10.14807/ijmp.v7i1.396

Ingaldi, M., \& Jursova, S. (2013). Wykorzystanie metody Servqual do badania satysfakcji klientów punktu obsługi indywidualnego klienta dystrybucji gazu. Rynek Energii, 107(4), 43-47.

Kardas, E. (2016). The assessment of quality of products using selected quality instruments. Production Engineering Archives, 10(1), 5-8. https://doi.org/10.30657/pea.2016.10.02

Kotus, M., Holota, T., Paulicek, T., Petrik, M., \& Sklenar, M. (2013). Quality and reliability of manufacturing process in automation of die-casting. In Z. Tkac, S. Pogran, J. Zarnovsky \& K. Kollarova, Advanced Materials Research (vol. 801, pp. 103-107).

https://doi.org/10.4028/www.scientific.net/AMR.801.103

Kujawiński, J. (1998). Niektóre metody oceny jakości usług. Marketing, 2(2001), 463-464.
Lupo, T. (2015). Fuzzy ServPerf model combined with ELECTRE III to comparatively evaluate service quality of international airports in Sicily. Journal of Air Transport Management, 42(2015, January), 249-259. https://doi.org/10.1016/j.jairtraman.2014.11.006

Mahmoud, A. B., \& Khalifa, B. (2015). A confirmatory factor analysis for SERVPERF instrument based on a sample of students from Syrian universities. Education and Training, 57(3), 343-359. https://doi.org/10.1108/ET-04-2014-0038

Matzler, K., Bailom, F., Hinterhuber, H. H., Renzl, B., \& Pichler, J. (2004). The asymmetric relationship between attribute-level performance and overall customer satisfaction: a reconsideration of the importance-performance analysis. Industrial Marketing Management, 33(4), 271-277.

https://doi.org/10.1016/S0019-8501(03)00055-5

Mbise, E. R., \& Tuninga, R. S. J. (2016). Measuring business schools' service quality in an emerging market using an extended SERVQUAL instrument. South African Journal of Business Management, 47(1), 61-74. https://doi.org/10.4102/sajbm.v47i1.53

Nilsson-Witell, L., \& Fundin, A. (2005). Dynamics of service attributes: a test of Kano's theory of attractive quality. International Journal of Service Industry Management, 16(2), 152-168. https://doi.org/10.1108/09564230510592289

Parasurman, A., Zeithaml, V. A., \& Berry, L. L. (1985). A conceptual model of service quality and its implications for the future research. Journal of Marketing, 49(4), 41-50. https://doi.org/10.2307/1251430

Reichheld, F. F. (2003). One number you need to grow. Harvard Business Review, 81(12), 46-54.

Rivière, P., Monrozier, R., Rogeaux, M., Pagès, J., \& Saporta, G. (2006). Adaptive preference target: Contribution of Kano's model of satisfaction for an optimized preference analysis using a sequential consumer test. Food Quality and Preference, 17(7), 572-581. https://doi.org/10.1016/j.foodqual.2006.04.002

Stoma, M. (2012). Modele i metody pomiaru jakości ustug ( $2^{\text {nd }}$ ed.). Lublin: Q\&R Polska Sp. z o.o.

Ulewicz, R. (2014. Application of Servqual method for evaluation of quality of educational services at the university of higher education. Polish Journal of Management Studies, 9, 254-264.

Wong, M. S., Hideki, N., \& George, P. (2011). The use of Importance-Performance Analysis (IPA) in evaluating Japan's E-government services. Journal of Theoretical and Applied Electronic Commerce Research, 6(2), 1730. https://doi.org/10.4067/S0718-18762011000200003 